Article

\title{
Enhanced Conversion Efficiency of a-Si:H Thin-Film Solar Cell Using ZnO Nanorods
}

\author{
Fang-I Lai ${ }^{1}$, Jui-Fu Yang ${ }^{2}$, Yu-Chao Hsu ${ }^{3,4}$ and Shou-Yi Kuo ${ }^{2,3, *}$ \\ 1 Electrical Engineering Program C, Yuan-Ze University, 135 Yuan-Tung Road, Chung-Li 32003, Taiwan; \\ filai@saturn.yzu.edu.tw \\ 2 Department of Electronic Engineering, Chang Gung University, 259 Wen-Hwa 1st Road, Kwei-Shan, \\ Taoyuan 333, Taiwan; yoharecca@gmail.com \\ 3 Department of Urology, Chang Gung Memorial Hospital, Linkou, No.5, Fuxing Street, Kwei-Shan, \\ Taoyuan 333, Taiwan; hsuyc@cgmh.org.tw \\ 4 School of Medicine, Chang Gung University, 259 Wen-Hwa 1st Road, Kwei-Shan, Taoyuan 333, Taiwan \\ * Correspondence: sykuo@mail.cgu.edu.tw; Tel.: +886-03-4228800
}

Received: 14 October 2020; Accepted: 24 November 2020; Published: 26 November 2020

\begin{abstract}
The surface reflectivity of a material will vary as light passes through interfaces with different refractive indices. Therefore, the optical loss and reflection of an optical-electronic component can be reduced by fabricating nanostructures on its surface. In the case of a solar cell, the presence of nanostructures can deliver many different advantages, such as decreasing the surface reflectivity, enhancing the light trapping, and increasing the efficiency of the carrier collection by providing a shorter diffusion distance for the photogenerated minority carriers. In this study, an approximately 50-nm thick seed layer was first prepared using spin coating. Zinc oxide nanorods (ZnO-NRs) were then grown using a chemical solution method (CSM). The ZnO-NRs were approximately $2 \mu \mathrm{m}$ in height and $100 \mathrm{~nm}$ in diameter. After applying them to amorphous silicon (a-Si:H) solar cells, the short-circuit current density increased from 8.03 to $9.24 \mathrm{~mA} / \mathrm{cm}^{2}$, and the photovoltaic conversion efficiency increased by $11.24 \%$.
\end{abstract}

Keywords: $\mathrm{ZnO}$ nanorods; antireflective layers; a-Si:H thin-film solar cell

\section{Introduction}

Solar cells made of a-Si:H films have long been the focus of attention. Compared to monocrystalline and polycrystalline silicon, a-Si:H has a relatively higher absorption coefficient. A merely $500-\mathrm{nm}$ thick a-Si:H film can absorb sufficient solar light and be made into efficient solar cells. In comparison, the thickness of a solar cell made of monocrystalline or polycrystalline silicon should reach hundreds of microns. Therefore, an a-Si:H thin-film solar cell not only can effectively reduce the costs, but it also has the potential to be applied to flexible substrates owing to its thinner thickness. In addition, an a-Si:H thin-film solar cell has gradually stood out from various solar cells in recent years and created a global increase in investment. Once large-size glass substrate thin-film solar cells are introduced into the market, they will significantly accelerate the promotion and popularization of photovoltaic building integration, rooftop grid-connected power generation systems, and photovoltaic power plants. In addition, an a-Si:H thin-film solar cell exhibits only weak attenuation under high-temperature conditions, making it suitable for the construction of power plants in high-temperature and desert areas. At present, although the efficiency of a-Si:H thin-film solar cells has reached 10\% [1], the high defect densities typically present in a-Si:H thin films limit the typical minority carrier diffusion lengths to $100 \mathrm{~nm}$; consequently, a-Si:H solar cells are generally fabricated using even thinner a-Si:H layers, resulting in reduced absorption of incident solar radiation. 
There are many approaches to increasing the light absorption, of which antireflective layers (ARLs) play an important role because they are capable of effectively reducing the Fresnel reflection loss at the interface between air and the top of the cell $[2,3]$. The common method of preparing an ARL is as follows: A single-layer or multi-layer ARL with a one-quarter wavelength of interest is used as silicon nitride and silicon oxide. However, single- or multi-layer ARLs have certain disadvantages such as the layer thickness control, material selection, material diffusion, a thermal expansion mismatch, and a small range of incident wavelengths and incident light angles [4]. In the past few years, it has been noted in different studies that a subwavelength grating (SWG) structure exhibits excellent broadband and omnidirectional antireflective optical properties, and the SWG of moth-eye pillars has thus begun to gradually replace traditional single- or multi-layer ARLs [5,6]. Fabrication processes involving electron beam lithography and dry etching have been widely used to fabricate various moth-eye structures in the past few years [7-9]. However, these fabrication processes are unsuitable for the mass production of nanostructures on large-area solar cells because the process-induced surface recombination defects reduce the performance of the device. Therefore, many scholars have developed bottom-up growth approaches to fabricate the nanostructures [10-12].

$\mathrm{ZnO}$ is a wide-direct band gap material for $3.37 \mathrm{eV}$ semiconductors and has been used in several $\mathrm{ZnO}$ structures as ARLs [13,14], including nanoflowers [15,16], nanorods $[17,18]$, nanotrees [19,20], and nanosheets [21,22]. However, the corresponding fabrication cost is high. The growth of $\mathrm{ZnO}$ nanostructures using the chemical solution method (CSM) approach, by contrast, carries significant potential. Compared to the traditional growth methods of $\mathrm{ZnO}$ nanostructures, the CSM approach has the advantages of low-temperature growth and low cost, in addition to its low technical threshold and large production capacity. Therefore, this study will fabricate zinc oxide nanorods (ZnO-NRs) on an a-Si:H thin-film solar cell using a CSM to improve the photovoltaic conversion efficiency.

According to the previous literature, D.N. Papadimitriou used electrochemical deposition (ECD) techniques to deposit $\mathrm{Al}: \mathrm{ZnO}-\mathrm{NR}$ as an antireflective layer on the surface of $\mathrm{Cu}(\mathrm{In}, \mathrm{Ga}) \mathrm{Se}_{2}$ solar cells. This structure effectively reduced the weighted global reflectance of devices by approximately $5 \%$ and improved the photoelectric conversion efficiency by approximately 5\% [13]. Xuegong Yu's team used the chemical solution method to grow $\mathrm{ZnO}$ nanowires with different lengths on the surface of polycrystalline silicon solar cells, thereby reducing the reflectivity of the device and improving the photoelectric conversion efficiency. Using this method, the photoelectric conversion efficiency was effectively improved by approximately 3\% [14]. In this study, CSM was used to grow ZnO nanorods on the surface of a-Si:H thin-film solar cell, which effectively improved the photoelectric conversion efficiency by approximately $11.24 \%$.

\section{Materials and Methods}

Before the growth process, the $\mathrm{Si}$ substrates were coated with a $\mathrm{ZnO}$ nanoparticle layer using a sol-gel preparation as the seeding layer. The crystalline seed layer was prepared in an environment of up to $140^{\circ} \mathrm{C}$, and was then annealed in an atmospheric environment. Next, the seed layer was placed in a chemical solution of $0.03 \mathrm{M}$ hexamethylenetetramine mixed with $0.03 \mathrm{M}$ zinc nitrate hexahydrate, and it was grown at $90{ }^{\circ} \mathrm{C}$ for $18 \mathrm{~h}$ to yield $\mathrm{ZnO}-\mathrm{NRs}$. The corresponding reaction formulas are as follows:

$$
\begin{gathered}
\mathrm{C}_{6} \mathrm{H}_{12} \mathrm{~N}_{4}+6 \mathrm{H}_{2} \mathrm{O} \rightarrow 6 \mathrm{HCHO}+4 \mathrm{NH}_{3} \\
\mathrm{NH}_{3}+\mathrm{H}_{2} \mathrm{O} \rightarrow \mathrm{NH}_{4}^{+}+\mathrm{OH}^{-} \\
\mathrm{Zn}^{2+}+2 \mathrm{OH}^{-} \rightarrow \mathrm{Zn}(\mathrm{OH})_{2} \\
\mathrm{Zn}(\mathrm{OH})_{2} \rightarrow \mathrm{ZnO}+\mathrm{H}_{2} \mathrm{O}
\end{gathered}
$$

The reflectivity of the $\mathrm{ZnO}-\mathrm{NRs}$ grown on the Si substrate and the $\mathrm{ZnO}$ seed layer was then measured using a UV-vis spectrometer. The entire fabrication process was then introduced to an a-Si:H film solar cell. The a-Si:H thin-film solar cells used in this study, as shown in Figure 1, are made of 
a-Si:H films applied at $140{ }^{\circ} \mathrm{C}$ with a very high frequency plasma enhanced chemical vapor deposition (VHF-PECVD) system operating at $40 \mathrm{MHz}$ with a power density of $83 \mathrm{~mW} / \mathrm{cm}^{2}$. On a SnO $2: \mathrm{F}$ substrate, doped layers with a thickness of $12 \mathrm{~nm}$ (p-layer) or $20 \mathrm{~nm}$ (n-layer) were synthesized using VHF-PECVD with an admixture of $10 \% \mathrm{~B}_{2} \mathrm{H}_{6}$ (p-layer) or $3 \% \mathrm{PH}_{3}$ (n-layer), respectively. After that, a 150-nm thick layer of $\mathrm{In}_{2} \mathrm{O}_{3}: \mathrm{Sn}$ (ITO) was deposited as a transparent conductive layer through DC-sputtering. Al was also deposited as an electrode using DC-sputtering.

(a)

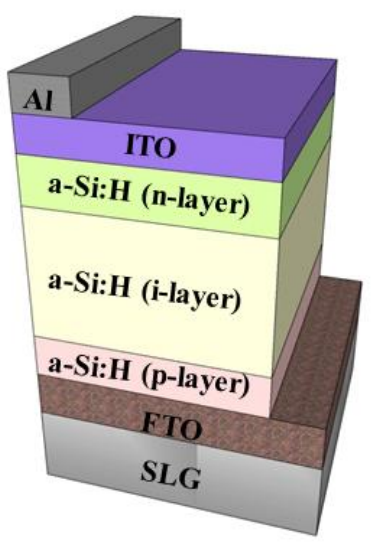

(b)

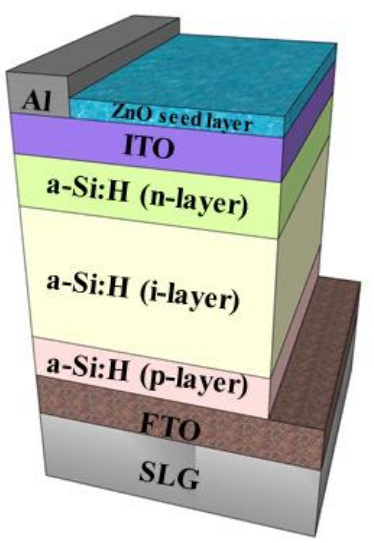

(c)

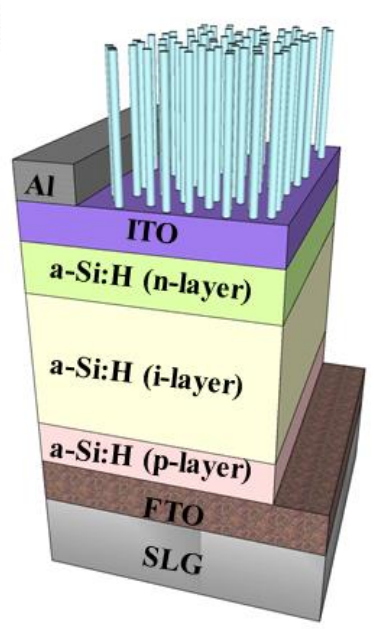

Figure 1. Schematic plot of the fabricated a-Si:H thin-film solar cell: (a) bare, (b) with a $\mathrm{ZnO}$ seed layer, and (c) with $\mathrm{ZnO}-\mathrm{NRs}$.

\section{Results}

Figure 2a,b shows the cross-sectional scanning electron microscope (SEM) views of the $\mathrm{ZnO}$ seed layer and the $\mathrm{ZnO}-\mathrm{NRs}$, respectively. It can be seen from Figure 2a that the thickness of the $\mathrm{ZnO}$ seed layer is approximately $50 \mathrm{~nm}$. From Figure $2 \mathrm{~b}$, it can be seen that the $\mathrm{ZnO}-\mathrm{NRs}$ are approximately $2 \mu \mathrm{m}$ in length. In addition, $\mathrm{ZnO}-\mathrm{NRs}$ demonstrated an average diameter of $100 \mathrm{~nm}$, shown in top view illustration in Figure 2.
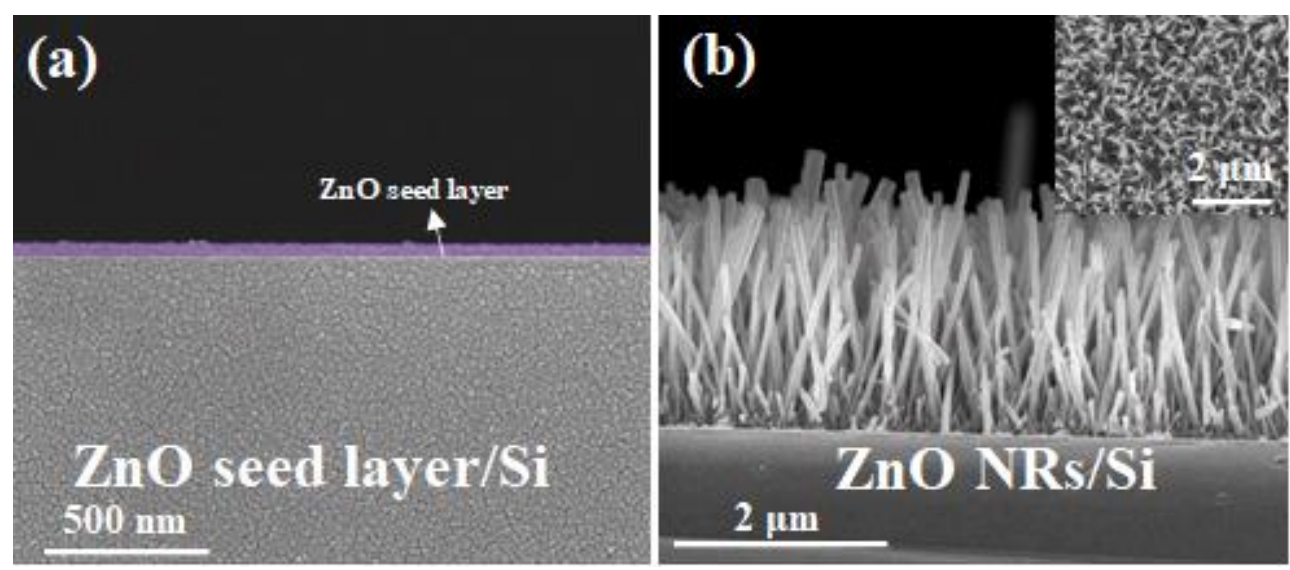

Figure 2. (a) Seed layer and (b) SEM cross-sectional view of ZnO-NRs; the illustration shows a top-view SEM of the ZnO-NRs.

Figure 3a shows an X-ray diffractometer (XRD) diagram of the ZnO-NRs grown on a Si substrate. Two distinct signals can be observed, which correspond to the $\mathrm{ZnO}(002)$ and $\mathrm{Si}(100)$ planes, respectively. Other compounds were not observed in XRD analysis. The full width at half maximum (FWHM) calculated from the XRD spectra is in indication of crystallinity, and our experimental results show 
that the value of FWHM $\left(\sim 0.35^{\circ}\right)$ is comparable to that reported in previous literature [23]. Generally, a lattice mismatch will exist between the different materials due to the difference in lattice constants of the constituent compounds. It is thought that strain effects can induce material distortion and microfracture, leading to device failure. Thus, in our study, the low-temperature buffer layer is introduced to accommodate lattice strain leading to the growth of almost strain-free $\mathrm{ZnO}$ nanorods. Our XRD results were consistent with JCPDS 36-1451. Therefore, it is speculated that the $\mathrm{ZnO}$ nanorods growing on the surface of a-Si:H solar cells showed a mismatch-strain-free characteristic. Furthermore, as seen in other literatures, nanostructures could still be used normally on devices after they pass the reliability and stability tests [24-26].

(a)

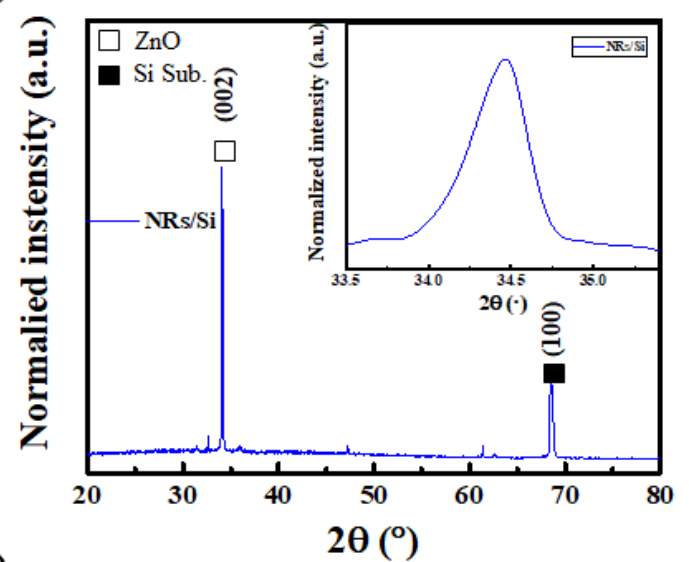

(c)

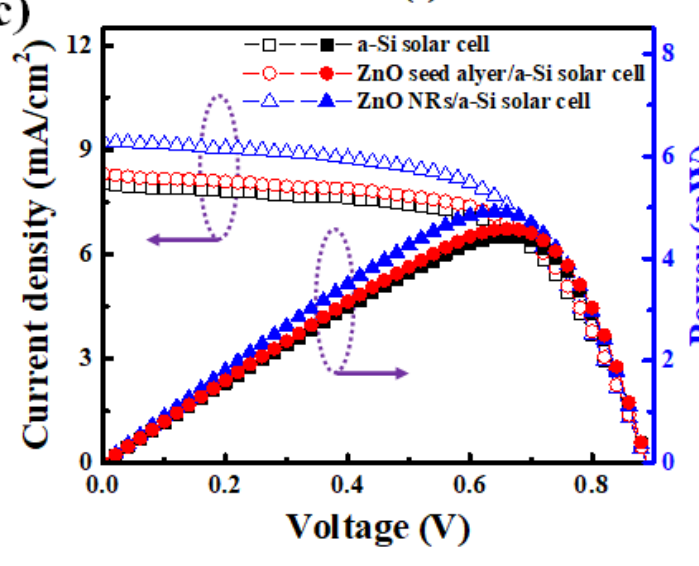

(b)

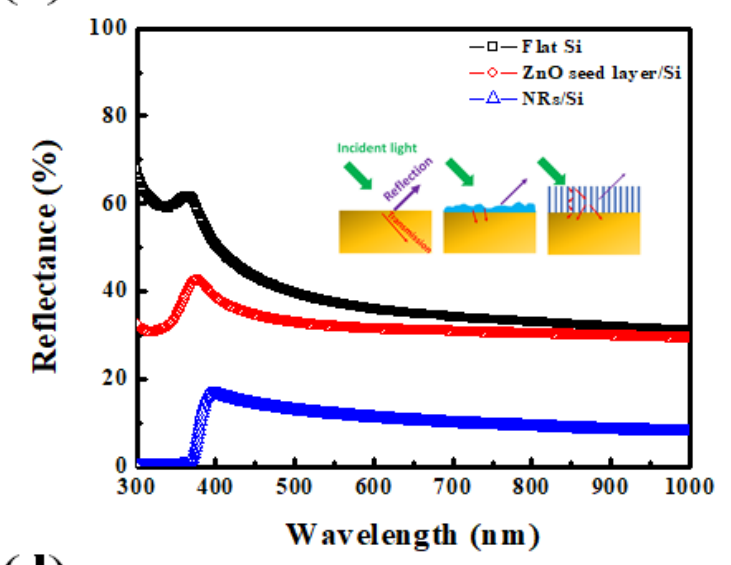

(d)

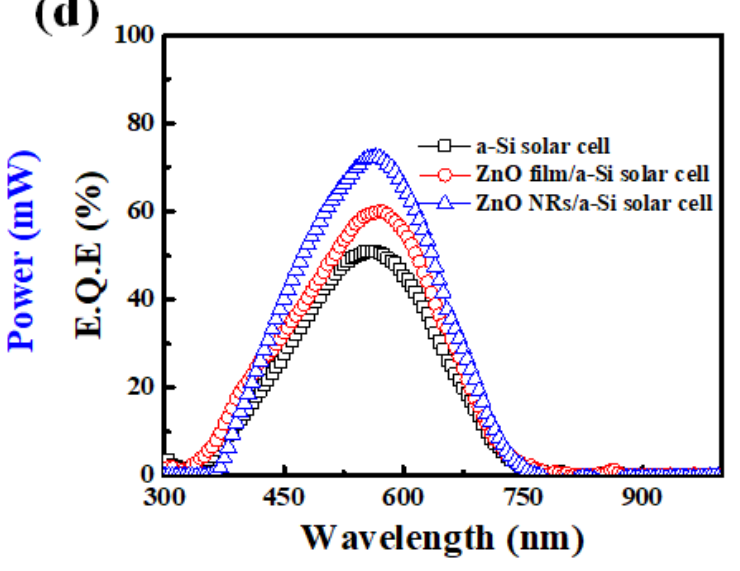

Figure 3. (a) XRD diagram of the ZnO-NRs, with the illustration showing an enlarged view of the plane (002); (b) reflectivity plot after depositing the $\mathrm{ZnO}$ seed layer and growing the ZnO-NRs on the Si substrate, (c) J-V curves of different antireflective layers (ARLs) growing on the a-Si:H thin-film solar cells under AM1.5 G (100 mW/cm²), and (d) EQE spectrum of different ARLs growing on a-Si:H thin-film solar cells.

Figure $3 \mathrm{~b}$ gives the reflectivity values of the $\mathrm{Si}$ substrate, the $\mathrm{ZnO}$ seed layer/Si, and the $\mathrm{ZnO}-\mathrm{NRs} / \mathrm{Si}$. Within the wavelength range of 300-1000 nm, the average reflectivity values of the Si substrate, the $\mathrm{ZnO}$ seed layer/Si, and the $\mathrm{ZnO}-\mathrm{NRs} / \mathrm{Si}$ are $39.05 \%$, 32.05\%, and $9.61 \%$, respectively. The slight reduction in reflectivity of the $\mathrm{ZnO}$ seed layer/Si might be attributed to the uneven surface topography. The main reason for the reduced reflectivity of $\mathrm{ZnO}-\mathrm{NRs} / \mathrm{Si}$ is the subwavelength structures produce a gradient refractive index profile between the material (refractive index $>1$ ) and air (refractive index $=1$ ) to reduce the Fresnel reflection and provide a more effective thermal stability and durability than surface coatings as only one material is used. Furthermore, the subwavelength structures are smaller than the wavelength of light and trap light through the diffraction of incident light in the nanostructure [27-29]. Figure 3c shows the current density-voltage (J-V) curves, which compare the 
differences among one bare a-Si:H thin-film solar cell, a cell with a $\mathrm{ZnO}$ seed layer coated on the ITO layer, and a cell with $\mathrm{ZnO}-\mathrm{NRs}$. The parameter arrangement from the experimental measurement results is listed in Table 1.

Table 1. Photovoltaic parameters of different antireflective layer film with a-Si:H thin-film solar cells.

\begin{tabular}{ccccc}
\hline Sample & Efficiency $(\mathbf{\%})$ & $\mathbf{V}_{\mathbf{o c}}(\mathbf{m V})$ & $\mathbf{J}_{\mathbf{s c}}\left(\mathbf{m A} / \mathbf{c m}^{\mathbf{2}}\right)$ & F.F. \\
\hline a-Si:H solar cell & 4.42 & 885 & 8.02 & 62.27 \\
\hline ZnO seed layer/a-Si:H solar cell & 4.57 & 885 & 8.3 & 62.21 \\
\hline ZnO NRs/a-Si:H solar cell & 4.98 & 885 & 9.24 & 60.9 \\
\hline
\end{tabular}

The conversion efficiencies $(\eta)$ of the bare solar cell and cells with a $\mathrm{ZnO}$ seed layer and $\mathrm{ZnO}-\mathrm{NRs}$ are $4.42 \%, 4.57 \%$, and $4.98 \%$, respectively. The open-circuit voltage $\left(\mathrm{V}_{\mathrm{oc}}\right)$ is approximately $885 \mathrm{mV}$; the fill factor (F.F.) is $60 \%$; and the short circuit current $\left(\mathrm{J}_{\mathrm{sc}}\right)$ values are $8.02,8.3$, and $9.24 \mathrm{~mA} / \mathrm{cm}^{2}$, respectively. Therefore, the increase in the efficiency of the a-Si:H thin-film solar cell mainly resulted from the increase in $\mathrm{J}_{\mathrm{sc}}$. The maximum increase in photocurrent enhancement factor $\left(\mathrm{EF}_{\mathrm{jsc}}\right)$ is $15.15 \%$, as calculated by the following formula:

$$
\mathrm{EF}_{\mathrm{jsc}}=\frac{\Delta \mathrm{J}_{\mathrm{sc}}}{\mathrm{J}_{\mathrm{sc}}}=\frac{\mathrm{J}_{\mathrm{sc}}(\text { with ARL })-\mathrm{J}_{\mathrm{sc}}(\text { without ARL })}{\mathrm{J}_{\mathrm{sc}}(\text { without ARL })}
$$

Figure $3 \mathrm{~d}$ shows the results of the external quantum efficiency (EQE) measurements, which also proved the increases in $\eta$ as a result of fabricating the $\mathrm{ZnO}$ seed layer and the $\mathrm{ZnO}-\mathrm{NRs}$ on the ITO layer. Compared with the bare a-Si:H thin-film solar cell, the cells with the $\mathrm{ZnO}$ seed layer and ZnO-NRs exhibited enhanced photo-responses within a wavelength range of approximately $400-750 \mathrm{~nm}$. Compared with a bare a-Si:H thin-film solar cell, the $\mathrm{ZnO}-\mathrm{NRs}$ exhibited a stronger antireflective property, which resulted in an improved $\mathrm{J}_{\mathrm{sc}}$ for the a-Si:H thin-film solar cell with ZnO-NRs.

\section{Conclusions}

In summary, the reflectivity of the a-Si:H thin-film solar cell was reduced significantly by fabricating the $\mathrm{ZnO}$ seed layer and the $\mathrm{ZnO}-\mathrm{NRs}$ on the ITO layer. Results showed that a $\mathrm{ZnO}$ seed layer was deposited on the surface of an a-Si:H thin-film solar cell as the ARL and the current density increased from the initial 8.02 to $8.3 \mathrm{~mA} / \mathrm{cm}^{2}$. The photoelectric conversion efficiency was improved by approximately $3.39 \%$. ZnO-NRs grown on the surface of an a-Si:H thin-film solar cell was used as ARL and the current density increased from the initial 8.02 to $9.24 \mathrm{~mA} / \mathrm{cm}^{2}$. The conversion efficiency of the solar cell increased from $4.42 \%$ to $4.98 \%$. This study has shown that ZnO-NRs can be used as an ARL for an a-Si:H thin-film solar cell, thereby providing a suitable alternative to other solar cells.

Author Contributions: Conceptualization: F.-I.L., and S.-Y.K.; methodology, J.-F.Y., and Y.-C.H.; validation, F.-I.L., S.-Y.K. and J.-F.Y.; formal analysis, Y.-C.H.; investigation, J.-F.Y. and Y.-C.H.; resources, F.-I.L., S.-Y.K. and Y.-C.H.; data curation, J.-F.Y.; writing-original draft preparation, J.-F.Y.; writing—review and editing, S.-Y.K.; supervision, S.-Y.K.; project administration, F.-I.L.; funding acquisition, F.-I.L., S.-Y.K. and Y.-C.H. All authors have read and agreed to the published version of the manuscript.

Funding: This research was funded by Chang Gung Memorial Hospital (BMRP 956) and Ministry of Science and Technology (MOST 108-2112-M-182-001-MY3, MOST 107-2221-E-155-055-MY3).

Acknowledgments: This research was supported by the Green Technology Research Center of Chang Gung University.

Conflicts of Interest: The authors declare no conflict of interest. The funders had no role in the design of the study; in the collection, analyses, or interpretation of data; in the writing of the manuscript; or in the decision to publish the results. 


\section{References}

1. Matsui, T.; Maejima, K.; Bidiville, A.; Sai, H.; Koida, T.; Suezaki, T.; Matsumoto, M.; Saito, K.; Yoshida, I.; Kondo, M. High-efficiency thin-film silicon solar cells realized by integrating stable a-Si:H absorbers into improved device design. Jpn. J. Appl. Phys. 2015, 54,08KB10. [CrossRef]

2. Li, D.; Liu, Z.; Wang, Y.; Shan, Y.; Huang, F. Efficiency Enhancement of Cu(In,Ga)Se 2 Solar Cells by Applying $\mathrm{SiO}_{2}$-PEG/PVP Antireflection Coatings. J. Mater. Sci. Technol. 2015, 31, 229-234. [CrossRef]

3. Chang, Y.-A.; Li, Z.-Y.; Kuo, H.-C.; Lu, T.-C.; Yang, S.-F.; Lai, L.-W.; Lai, L.-H.; Wang, S.-C. Efficiency improvement of single-junction InGaP solar cells fabricated by a novel micro-hole array surface texture process. Semicond. Sci. Technol. 2009, 24, 085007. [CrossRef]

4. Baek, S.-H.; Kim, S.-B.; Shin, J.-K.; Kim, J.-H. Preparation of hybrid silicon wire and planar solar cells having $\mathrm{ZnO}$ antireflection coating by all-solution processes. Sol. Energy Mater. Sol. Cells 2012, 96, 251-256. [CrossRef]

5. Shao, T.; Tang, F.; Sun, L.; Ye, X.; He, J.; Yang, L.; Zheng, W. Fabrication of Antireflective Nanostructures on a Transmission Grating Surface Using a One-Step Self-Masking Method. Nanomaterials 2019, 9, 180. [CrossRef]

6. Rouzo, J.-L.; Brückner, J.-B.; Ferchichi, A.; Gourgon, C.; Berginc, G.; Escoubas, L. Optical properties of antireflective flat or rough patterned topped silicon cones gratings. Adv. Device Mater. 2015, 1, $23-26$. [CrossRef]

7. Ducros, C.; Brodu, A.; Lorin, G.; Emieux, F.; Pereira, A. Optical performances of antireflective moth-eye structures. Comparison with standard vacuum antireflection coatings for application to outdoor lighting LEDs. Surf. Coat. Technol. 2019, 379, 125044. [CrossRef]

8. Liu, Y.; Soltani, M.; Dey, R.-K.; Cui, B.; Lee, R.; Podmore, H. Moth-eye antireflection nanostructure on glass for CubeSats. J. Vac. Sci. Technol. B 2018, 36, 06JG01. [CrossRef]

9. Lotz, M.-R.; Petersen, C.-R.; Markos, C.; Bang, O.; Jakobsen, M.-H.; Taboryski, R. Direct nanoimprinting of moth-eye structures in chalcogenide glass for broadband antireflection in the mid-infrared. Optica 2018, 5, 557-563. [CrossRef]

10. Ren, X.; Sangle, A.; Zhang, S.; Yuan, S.; Zhao, Y.; Shi, L.; Hoye, R.-L.-Z.; Cho, S.; Li, D.; MacManus-Driscoll, J.-L. Photoelectrochemical water splitting strongly enhanced in fast-grown $\mathrm{ZnO}$ nanotree and nanocluster structures. J. Mater. Chem. A 2016, 4, 10203-10211. [CrossRef]

11. Son, D.-Y.; Im, J.-H.; Kim, H.-S.; Park, N.-G. 11\% Efficient Perovskite Solar Cell Based on ZnO Nanorods: An Effective Charge Collection System. J. Phys. Chem. C 2014, 118, 16567-16573. [CrossRef]

12. Jin, D.; Gu, X.; Yu, X.; Ding, G.; Zhu, H.; Yao, K. Hydrothermal synthesis and characterization of hexagonal $\mathrm{Mg}(\mathrm{OH})_{2}$ nano-flake as a flame retardant. Mater. Chem. Phys. 2008, 112, 962-965. [CrossRef]

13. Papadimitriou, D.-N. Structural, optical, electrical properties, and strain/stress of electrochemically deposited highly doped $\mathrm{ZnO}$ layers and nanostructured $\mathrm{ZnO}$ antireflective coatings for cost-effective photovoltaic device technology. Thin Solid Films 2016, 605, 215-231. [CrossRef]

14. Yu, X.; Dong, W.; Dong, L.; Li, G.; Yang, D. Efficiency improvement of silicon solar cells enabled by ZnO nanowhisker array coating. Nanoscale Res. Lett. 2012, 7, 306. [CrossRef] [PubMed]

15. Rupa, E.-J.; Kaliraj, L.; Abid, S.; Yang, D.-C.; Jung, S.-K. Synthesis of a Zinc Oxide Nanoflower Photocatalyst from Sea Buckthorn Fruit for Degradation of Industrial Dyes in Wastewater Treatment. Nanomaterials 2019, 9, 1692. [CrossRef]

16. Upadhyay, A.; Yang, H.; Zaman, B.; Zhang, L.; Wu, Y.; Wang, J.; Zhao, J.; Liao, C.; Han, Q. ZnO Nanoflower-Based NanoPCR as an Efficient Diagnostic Tool for Quick Diagnosis of Canine Vector-Borne Pathogens. Pathogens 2020, 9, 122. [CrossRef]

17. Bhushan, B.; Murty, B.-S.; Mondal, K. A new approach for synthesis of ZnO nanorod flowerets and subsequentpure free-standing $\mathrm{ZnO}$ nanorods. Adv. Powder Technol. 2019, 30, 30-41. [CrossRef]

18. Li, X.; Chen, X.; Yi, Z.; Zhou, Z.; Tang, Y.; Yi, Y. Fabriction of ZnO Nanorods with Strong UV Absorption and Different Hydrophobicity on Foamed Nickel under Different Hydrothermal Conditions. Micromachines 2019, 10, 164. [CrossRef]

19. Zhao, F.; Zheng, J.-G.; Yang, X.; Li, X.; Wang, J.; Zhao, F.; Wong, K.-S.; Liang, C.; Wu, M. Complex ZnO nanotree arrays with tunable top, stem and branch structures. Nanoscale 2010, 2, 1674-1683. [CrossRef]

20. Zhao, F.; Li, X.; Zheng, J.-G.; Yang, X.; Zhao, F.; Wong, K.-S.; Wang, J.; Lin, W.; Wu, M.; Su, Q. ZnO Pine-Nanotree Arrays Grown from Facile Metal Chemical Corrosion and Oxidation. Chem. Mater. 2008, 20, 1197-1199. [CrossRef] 
21. Iqbal, T.; Khan, M.-A.; Mahmood, H. Facile synthesis of ZnO nanosheets: Structural, antibacterial and photocatalytic studies. Mater. Lett. 2018, 224, 59-63. [CrossRef]

22. Dahiya, A.-S.; Sporea, R.-A.; Poulin-Vittrant, G.; Alquier, D. Stability evaluation of ZnO nanosheet based source-gated transistors. Sci. Rep. 2019, 9, 2979. [CrossRef] [PubMed]

23. Shabannia, R. Vertically aligned $\mathrm{ZnO}$ nanorods on porous silicon substrates: Effect of growth time. Prog. Nat. Sci. Mater. Int. 2015, 25, 95-100. [CrossRef]

24. Yao, I.-C.; Lin, P.; Tseng, T.-Y. Field Emission Properties and Reliability of ZnO Nanorod, Nanopagoda, and Nanotip Current Emitters. IEEE Trans. Nanotechnol. 2012, 11, 746-750. [CrossRef]

25. Ye, Z.; Ji, X.; Zhang, Q. Enhanced field emission properties of ZnO nanorods by surface modification. RSC Adv. 2015, 5, 78502-78507. [CrossRef]

26. Lai, F.-I.; Yang, J.-F.; Liao, W.-X.; Kuo, S.-Y. Enhanced omnidirectional and weatherability of $\mathrm{Cu}_{2} \mathrm{ZnSnSe}_{4}$ solar cells with ZnO functional nanorod arrays. Sci. Rep. 2017, 7, 14927. [CrossRef]

27. Lalanne, P.; Morris, G.-M. Antireflection behavior of silicon subwavelength periodic structures for visible light. Nanotechnology 1997, 8, 53-56. [CrossRef]

28. Chiu, M.-Y.; Chang, C.-H.; Tsai, M.-A.; Chang, F.-Y.; Yu, P. Improved optical transmission and current matching of a triple-junction solar cell utilizing sub-wavelength structures. Opt. Express 2010, 18, A308-A313. [CrossRef]

29. Leem, J.-W.; Joo, D.-H.; Yu, J.-S. Biomimetic parabola-shaped AZO subwavelength grating structures for efficient antireflection of Si-based solar cells. Sol. Energy Mater. Sol. Cells 2011, 95, 2221-2227. [CrossRef]

Publisher's Note: MDPI stays neutral with regard to jurisdictional claims in published maps and institutional affiliations.

(C) 2020 by the authors. Licensee MDPI, Basel, Switzerland. This article is an open access article distributed under the terms and conditions of the Creative Commons Attribution (CC BY) license (http://creativecommons.org/licenses/by/4.0/). 